\title{
DROGA KRZYŻOWA JAKO METAFORA PRZEMIJANIA
}

Tekst drogi krzyżowej, podzielony według struktury 14 stacji, stanowi zapis ostatnich chwil Chrystusa, począwszy od sądu i skazania Go na śmierć przez Piłata po moment złożenia ciała do grobu. Metaforyzacja pozwala odczytywać tę formę pasyjną poprzez ludzką egzystencję i determinujące ją problemy. Umożliwia więc osobom podejmującym drogę na Golgotę konfrontowanie się z postacią Chrystusa. Spotkanie to pozwala stawiać pytania istotne z punktu widzenia konkretnego człowieka i poszukiwać na nie odpowiedzi. Wymiar ludzki dominuje podczas tej procesji. Znaczącym dla jej wymowy okazuje się bowiem fakt, iż Chrystus na czas męki wyzbył się swej boskiej natury i stał się człowiekiem. Wymiar duchowy, o którym nie można zapominać, sprowadza się do poszukiwania sensu tego dramatycznego misterium. Jednym z metaforycznych odczytań 14 stacji drogi krzyżowej staje się też postrzeganie ich jako zapisu ludzkiego przemijania, ukazanego w sposób drastyczny, ze szczególnym uwzględnieniem momentalności tego procesu. Niniejsze studium ma celu wskazanie i scharakteryzowanie obecności refleksji nad przemijaniem we współczesnych rozważaniach drogi krzyżowej ${ }^{1}$. Stanowią one rozwinięcie 14 stacji tego pasyjnego nabożeństwa.

\section{Charakter TEKSTU Drogi KRZYŻOWEJ A PROBLEMATYKA PRZEMIJANIA}

Droga krzyżowa to nabożeństwo paraliturgiczne, którego istotą jest procesyjny ruch w obrębie 14 stacji. Obecna postać tychże stacji, a także ich chronologia, została ukształtowana dzięki wielowiekowym chrześcijańskim praktykom pasyjnym² ${ }^{2}$. Do

\footnotetext{
* Monika Bednarczyk - doktorantka Wydziału Filologicznego Uniwersytetu Pedagogicznego w Krakowie, specjalność literaturoznawcza. Zajmuje się tekstami rozważań drogi krzyżowej, interesuje również poetyką przestrzeni. Dotychczasowe publikacje: Wyrazić niewyrażalne - o emocjonalności tekstów pasyjnych, [w:] Emocje. Ekspresja. Poetyka. Przeglad zagadnień, red. D. Saniewska, Białystok 2013; Antropologiczne ścieżki Seweryna Pollaka, „Teologia Młodych” 2012, nr 1; Nieskończona jest rola dźwigacza sensu. O znaczeniu ruchu w twórczości Brunona Schulza, „Zeszyty Naukowe Towarzystwa Doktorantów Uniwersytetu Jagiellońskiego Seria Nauk Humanistycznych” 2012, nr 4; Gdzie jest dom w "Ogrodach" Jarostawa Iwaszkiewicza, „Anthropos?” 2011, nr 16-17.

${ }^{1}$ Rozważania drogi krzyżowej przywoływane w pracy powstały w XX i XXI wieku.

${ }^{2}$ Proces kształtowania się obowiązującej współcześnie struktury drogi krzyżowej rozpoczął się w okresie wypraw krzyżowych (XI w.). Encyklopedia katolicka wyznacza granicę wieku XVIII jako moment jego zakończenia. Cezura ta okazuje się dla badaczy sporna.14 stacji funkcjonuje jednak już zgodnie w popularnych modlitewnikach drukowanych w wieku XIX i XX. Na potrzeby niniejszej pracy, przy-
} 
tej struktury odwołują się współczesne teksty dróg krzyżowych. Ich najistotniejszym elementem są jednak rozważania. Towarzyszą one procesji (podczas nabożeństwa) lub stanowią wynik jej prywatnego kontemplowania (w oderwaniu od liturgii). Struktura 14 stacji, staje się wobec rozważań cyklem narracyjnym złożonym z konstatacji — stwierdzeń szkicujących przebieg opowieści. Czas i miejsce cyklu odwołują się do przestrzeni jerozolimskiej i wydarzeń, jakie towarzyszyły prowadzonemu na śmierć Jezusowi z Nazaretu. Struktura ta ma charakter spajający, ujmuje opowieść w klamrę. Można zatem określić ją mianem narracji prymarnej. W jej tok następnie zostaje włączona indywidualna opowieść głosu — bohatera, który podejmuje się rozwinięcia tego pasyjnego tematu, spisując rozważania stanowiące dialog z poszczególnymi stacjami $^{3}$. Tak tworzy się drugi, niepowtarzalny poziom tekstu. Przy czym często również struktura drogi krzyżowej za sprawą dialogicznego charakteru rozważań, poddawana jest przekształceniom. Liczba stacji zostaje zwiększona lub w inny sposób zdefiniowana. Aktualizacja opowieści poprzez treść rozważań odwołujących się do teraźniejszości wymusza więc na formie pasyjnej plastyczność. Istota prymarnej narracji wciąż jednak zostaje zachowana.

Odwoływanie się do jerozolimskiego czasu i miejsca, sięganie po formę drogi krzyżowej staje się też pretekstem do mierzenia się z naturą człowieka. Los Chrystusa, Boga-człowieka, cierpiącego ogromny ból z powodu swej cielesności, służy do budowania podstaw własnej opowieści w oparciu o analogie bądź opozycje. Droga krzyżowa oznacza konfrontację z fizycznym aspektem życia ludzkiego oraz mierzenie się psychiki z faktem utraty witalności. Gwałtowność zmian, jakie ukazuje pasja, może prowadzić do skrajnych emocji, wywoływać szok bądź bunt. Nie jest to jedynie proste podobieństwo w wyraźnych granicach przemierzanej drogi człowieka od narodzin po

wołującej teksty współczesne, uznaje się zatem tę właśnie postać i liczbę stacji za tradycyjną. Ona, jak można przypuszczać, stanowi inspirację dla powstających obecnie rozważań.. Zob. Encyklopedia katolicka, red. R. Łukaszczyk, L. Bieńkowski, F. Grylewicz, t. 4, Lublin 1983, s. 215-221; Katolik na modlitwie i nauce, czyli zbiór obowiazków i nabożenstwa dla osób wszelkiego stanu z dodatkiem katechizmu i pieśni, Kraków 1872, s. 408-425; Droga krzyżowa. Nabożénstwo ku czci bolesnej męki i śmierci Pana Naszego Jezusa Chrystusa i Jego Matki Najświętszej Panny Bolesnej: do użytku kościelnego i domowego, Bytom 1895. $\mathrm{O}$ ewolucji struktury drogi krzyżowej w szerszym kontekście tradycji pasyjnej i związanych z nią innych form paraliturgicznych zob. także M. Kuran, Polska religijność pasyjna w świetle kazań wielkopiatkowych (1702-1732) z biblioteki klasztoru Reformatów w Zakliczynie, [w:] Miscellanea literackie i teatralne (od Kochanowskiego do Mrożka). Profesorowi Janowi Okoniowi przez przyjaciót i uczniów na 70. urodziny zebrane, red. K. Płachcińska, M. Kuran, cz. 1, Łódź 2010, s. 419-455.

${ }^{3}$ Odwołuję się w tym miejscu do rozróżnienia na tekst prymarny i włączony, scharakteryzowanych w pracy Mieke Bal, Narratologia. Wprowadzenie do teorii narracji (przekł. zespół tłumaczy Instytutu Filologii Polskiej UAM w Poznaniu, Kraków 2012, s. 57-58): „[...] związek tekstu narratora i tekstu aktora wskazuje na różnicę poziomów. Ostatecznie tekst narracyjny tworzy przecież całość, w której w tekst narratora włączone są inne teksty. Zależność tekstu aktora od tekstu narratora powinna być rozumiana jako zależność zdania podrzędnego od zdania głównego. Zgodnie z tą zasadą teksty narratora i aktora nie mają równego statusu. Hierarchiczna pozycja tekstów wynika z podstawowej zasady poziomów. Relacje między tekstem narratora a tekstem aktora mogą się różnić formą i intensywnością. Ważny jest tutaj aspekt ilościowy: im więcej zdań obudowuje tekst aktora, tym silniejsza jest jego zależność”. 
śmierć oraz Chrystusa od sądu po grób. Obraz agonii ukazany w drodze krzyżowej stoi w opozycji wobec współczesnego tabu, jakim objęte jest nie tylko starzenie się i śmierć, lecz również żałoba, która będąc długotrwałym procesem, nie wpisuje się w intensywność charakteryzującą obecnie ludzkie życie. Korzenie problemu sięgają społecznych przemian wieku XX:

Wiele jest przyczyn marginalizacji śmierci i zmarłych w XX wieku, nawet jeśli postrzegamy je jako całość. Wśród głównych tematów skłonni jesteśmy od razu wymienić (nie wybiegając zbytnio naprzód) komercjalizację, która włącza śmierć w cykl konsumpcji — od trumny po cmentarz, oraz medykalizację, przejmującą poprzez hospitalizację pełną opiekę nad chorym i umierającym. Przede wszystkim zaś deprecjację (przyczyna to czy konsekwencja?) tych struktur rodzinnych czy też wspólnotowych, w których ramach organizowano w XIX wieku wszelkie obrzędy związane ze śmiercią ${ }^{4}$.

Świadomość własnej śmiertelności zdaje się zatem kluczem do rozumienia drogi krzyżowej jako metafory przemijania. Co więcej, dążenie do konfrontacji z tematem śmierci, niejakie przyglądanie się i rozważanie agonii ludzkiej, w kontekście przywołanych diagnoz wyparcia problemu, czyni to zjawisko wyjątkowym.

Śmiertelność nadaje egzystencji charakter procesualny. Przemijanie łączy zatem biegunowe stany człowieka: młodość i starość. Staje się wyrazem ludzkiej metamorfozy. Śmiertelność stymuluje istotę ludzką do poszukiwania tożsamości i sensu życia, a w dalszej kolejności do spełniania swego powołania. Znikomość bytu budzi w niej również pragnienie wieczności. Wyraża się ono w dwojaki sposób. Jest wypracowywaniem za życia pośmiertnego zbawienia duszy. Może także stać się próbą ustanowienia trwałego znaku swojej minionej obecności w historii. Tak też aspekt cielesności łączy się $\mathrm{w}$ drodze krzyżowej z wymiarem duchowym, rozumianym jako pierwiastek nieprzemijalny człowieka. Warto zatem rozróżnić dwa pojęcia regulujące napięcie pomiędzy znikomością ciała i stałością ducha.

Przemijanie, termin rozumiany przez Helmuta Thielicke jako „cecha i właściwość samego życia” nie zaś to, co „życiu się przydarza”, wiąże się z biologicznym pojmowaniem śmierci. Cataldo Zuccaro rozwinął tę myśl, tworząc trójwymiarowe spojrzenie (z punktu widzenia teologicznego) na kwestię śmiertelności:

Od samego początku śmierć chrześcijanina była związana ze śmiercią Chrystusa, jednak nie traciła ona przez to swego charakteru powszechności, ani cech biologicznych. Zasadniczo w tradycji kościelnej spotyka się trzy perspektywy, w których rozumie się wydarzenie śmierci: jako rzeczywistość dotycząca wszystkich ludzi i coś naturalnego; jako rzeczywistość będąca skutkiem grzechu; jako okazję do zjednoczenia z Chrystusem, który przemienił przekleństwo śmierci w błogosławieństwo ${ }^{6}$.

\section{Dalej Zuccaro pisał jednak:}

W ciagłości doświadczenia śmierci jako niepożądanej i jako czegoś, co osiąga człowiek bierny wobec niej (Lévinas), także interpretacja teologiczna, wychodząc od postawy Chrystusa, widzi w śmierci „ab-

\footnotetext{
${ }^{4}$ M. Vovelle, Śmierć w cywilizacji Zachodu. Od roku 1300 po wspótczesność, wyd. 2, przekł. T. Swoboda, M. Ochab, M. Sawiczewska-Lorkowska, D. Senczyszyn, Gdańsk 2008, s. 651.

${ }^{5}$ H. Thielicke, Życie ze śmiercia, przekł. S. Szczyrbowski, Warszawa 2002, s. 58.

${ }^{6}$ C. Zuccaro, Teologia śmierci, przekł. K. Stopa, Kraków 2004, s. 103.
} 
surd” i „odrazę”, a jednak, na podobieństwo doświadczenia antropologicznego śmierci jako aktywności (Heidegger), pozostaje ona doświadczeniem głęboko ludzkim, „okazją, w której człowiek może i powinien ukazać się jako człowiek"”.

Los człowieka i Chrystusa zostaje w drodze krzyżowej złączony. Zdążanie do grobu i związany z tym podążaniem strach, melancholia, odrzucenie, przeplatają się z wątłą, lecz jednak nadzieją na wybawienie (nadejście kresu), zbawienie (zyskanie wieczności różnie rozumianej) i akceptacji siebie jako człowieka. Potrzeba akceptacji wynika więc ze statusu samego Chrystusa, który odarty ze swej nieśmiertelności zostaje wystawiony na próbę ciała, ta zaś kończy się śmiercią. A zatem już na tym poziomie (narracji prymarnej) tekstu drogi krzyżowej, widoczne staje się napięcie rodzące się w obliczu doświadczenia śmierci na granicy myśli egzystencjalnej, eschatologicznej oraz mistycznej.

\section{OBRAZ PRZEMIJANIA I ŚMIERCI W ROZWAŻANIACH DROGI KRZYŻOWEJ}

Cykl 14 stacji otwiera sąd. Ks. Jerzy Popiełuszko napisał we wstępie do własnych rozważań: „Życie nasze jest drogą krzyżową. Ledwie narodzimy się, a już umieramy, jesteśmy coraz bliżej śmierci. Idziemy od jednego zmartwienia do drugiego, upada-

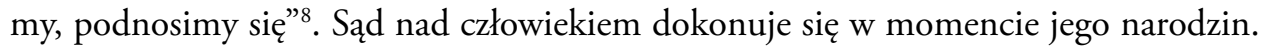
Chwila ta inicjuje proces przemijania. Człowiek skazany na śmierć od początku intuicyjnie poszukuje wyjaśnienia przyczyn trudnego dla niego położenia. Wyrazem jego niepokoju w rozważaniach drogi krzyżowej staje się powrót do początku, którego symbolem jest ogród. To właśnie w miejscu ustronnym (refugium) zostało postawione pytanie o sens cierpienia. Niektórzy autorzy rozważań pierwszą stację umieszczają w Getsemani. Ks. Piotr Zaborski tak pisał o modlitwie Chrystusa w Ogrójcu, otwierając tą sceną swój cykl pasyjny:

[...] oni nie przeczuwali, że godzina Jego odejścia jest już bliska.

W Getsemani rozpoczyna się godzina Jezusa.

Przyszedł na świat dla tej właśnie godziny.

Do tej chwili przygotowywał się całe swoje życie ${ }^{10}$.

Interpretacja zdarzenia rozgrywającego się w Ogrodzie Oliwnym pozwala autorowi rozważań postawić pytanie o sens ludzkiej egzystencji. Wiąże się ono nierozerwalnie, według ks. Zaborskiego, z powołaniem do określonego działania, którego kres pieczętuje spełnienie swojego losu. Współczesna mistyka podpowiada więc słowami

\footnotetext{
${ }^{7}$ Tamże, s. 104-105.

${ }^{8}$ J. Popiełuszko, Żyć i umierać z nadzieją: droga krzyżowa, Częstochowa 2011, s. 3.

${ }^{9}$ Rozważania ks. Zaborskiego stanowią komentarz do plastycznego wyobrażenia drogi krzyżowej autorstwa Stanisława Rodzińskiego. Cykl szesnastu obrazów poświęconych Pasji został wystawiony w Częstochowie w 2010 roku przy okazji Międzynarodowego Festiwalu Muzyki Sakralnej Gaude Mater. Dzieła Rodzińskiego wraz z rozważaniami ks. Zaborskiego, duszpasterza Częstochowskich Środowisk Twórczych, zostały następnie wydane we wspólnej publikacji.
}

${ }^{10}$ P. Zaborski, Rozważania drogi krzyżowej,[w:] S. Rodziński, Droga krzyżowa, Częstochowa 2010, s. 4. 
Willigisa Jägera: „Dopełnij swoje narodziny. To zadanie naszego życia. Dopełniamy je nie poprzez dokonania, lecz poprzez bycie. Doświadczenie bycia, doświadczenie naszej najgłębszej istoty [...]"11. Myśl ta koresponduje z procesualnym postrzeganiem ludzkiej egzystencji przez Martina Heideggera. Świadomość czasu i chęć dopełnienia się w czasie towarzyszy teraźniejszości i determinuje ją. Bycie ku śmierci staje się kluczowe dla ludzkiej egzystencji, gdyż stwarza ciągłą możliwość postrzegania siebie jako istoty rozwijającej się i poszukującej kompletności swego ja. Dopiero śmierć zatrzymuje ten niekończący się za życia proces nadawania sobie kształtu ${ }^{12}$.

Przywołanie sceny z Ogrodu Oliwnego sugeruje nie tylko zgodę na śmierć, która dokona się na końcu jeszcze właściwie nie rozpoczętej drogi, lecz ma za zadanie przyjrzeć się niedoskonałości ciała, mogącego jawić się wielokrotnie jako obce. Siostra Imelda Kosmala ${ }^{13}$ napisała o spotkaniu w Ogrójcu, tytułując je cytatem z Ewangelii św. Marka, „Nie jako ja chcę”, w sposób następujący:

Do ostatniej nocy Twojej wolności

Chryste bezsilny z wyboru

wobec sytuacji policzonych godzin

najbardziej ludzki z człowieczych synów -

do Twojego ciała zlanego potem i krwią

do oblicza wciśniętego w ziemię

przychodzę $e^{14}$.

Ciało, które dopiero czeka agonia, już w tym opisie staje się nieestetyczne — pokrywa je pot i krew, twarz spoczywająca na ziemi brudna jest od prochu. Do tak ukazanego człowieka zbliżamy się, by poznać charakter ludzkiego kresu. Thielicke zwrócił i na to uwagę:

Prawda o ludzkiej śmierci wychodzi na jaw dopiero wtedy, gdy mogę powiedzieć w pierwszej osobie „ja umieram”, kiedy więc śmierć rozumiem jako moją, mnie dotyczącą. Dopiero wtedy, gdy chodzi o moją własną śmierć, przestaje ona być zjawiskiem ogólnym i dlatego wciąż półprawdziwym i staje się przeżyciem osobowym, w którym doświadczam tajemnicy mojego istnienia. Śmierć musi więc zbliżyć się do mnie ${ }^{15}$.

Skazujemy się więc na widok cudzej agonii, by w sposób jedyny z możliwych przeżyć ją za życia. Chrystus bierze zatem krzyż na swe ramiona, jak głosi stacja II, a Marek Skwarnicki tak to skomentował:

\footnotetext{
${ }^{11}$ W. Jäger, Życie nigdy się nie kończy. O życiu, starości i śmierci, przekł. Z. Mazurczak, Warszawa 2007, s. 52.

${ }^{12}$ M. Heidegger, Bycie i czas, przekł. B. Baran, Warszawa 1994, s. 332-375.

${ }^{13}$ Siostra Maria Imelda Kosmala była zakonnicą związaną z Prowincją Warszawską Zgromadzenia Sióstr Felicjanek. Zmarła w 1994 roku w wieku 60 lat. Zbiór jej wierszy został opublikowany z okazji 75-lecia Prowincji Warszawskiej. Siostra Imelda w zakonie spędziła 41 lat. Jedną z jej aktywności była twórczość poetycka, której treść stała się inspiracją dla innych sióstr zgromadzenia. We wstępie do tomiku czytamy o autorce następujące słowa: „Jest jedną z tych, które tworzyły kształt i jakość naszego życia”. Cyt. za M. B. Klimanowska, Poszukując odpowiedzi na pytanie o sens, [w:] M. I. Kosmala, Ku twarzy wędruję. Wybór wierszy, Warszawa 1997, s. 10.

${ }^{14}$ M. I. Kosmala, Śladami Męki Mojego Pana, [w:] taż, Ku twarzy wędruję, s. 69.

${ }^{15}$ H. Thielicke, dz. cyt., s. 23.
} 
Chrystus, przyjmując krzyż na swe ramiona,

wszedł w ból i samotność wszystkich ludzi,

którzy wiedzą, że niebawem umrą

lub trwają w odrętwieniu ostatnich cierpien ${ }^{16}$.

Skwarnicki odwołał się do wspólnoty doświadczenia, w jaką niewątpliwie wpisuje się przemijanie. Pozwala to nadać męce Chrystusa charakter uniwersalny — odnoszący się do każdej egzystencji, ale i każdemu typowi agonii, niezależnie od jej przyczyny. Samotność i ból, jak można przypuszczać ból psychiczny, czyni umieranie jednym i tym samym bez względu na okoliczności.

Osamotnienie, właśnie ten aspekt pasji zwraca również uwagę Julii Kristevy podczas jej analizy przedstawienia Jezusa złożonego do grobu według holenderskiego malarza:

W Bazylei Chrystus Holbeina jest sam — pisała — Kto go widzi? Nie ma świętych. Jest oczywiście malarz. I my. Aby zatonąć w śmierci lub, być może, ujrzeć ją w jej minimalnym, przerażającym pięknie, na granicy życia ${ }^{17}$.

Ten, kto umiera, pozostaje wykluczony. My, zbiorowość trzymająca się wciąż kurczowo życia, jesteśmy zdolni doświadczać śmierci jak zjawiska estetycznego, musimy jedynie przekonać się i na moment spojrzeć, spróbować zaobserwować powierzchowne cechy tego granicznego doświadczenia.

Jako że przemijanie dotyczy ciała, warto zapytać o oprawcę owego ciała. Jakie przyjmuje maski? Do kwestii tej odnoszą się w szczególny sposób stacje, upamiętniające upadki Chrystusa.

Choroba - to pierwszy z tematów, który można zaobserwować w tekstach dróg krzyżowych. Wiąże się z wykluczeniem. W rozważaniach opracowanych na potrzeby nabożeństwa dedykowanego przestrzeni obozu zagłady Auschwitz-Birkenau ${ }^{18}$, przytoczono w miejscu pierwszego upadku Chrystusa słowa psalmisty:

Jestem zgnębiony, nad miarę pochylony,

przez cały dzień chodzę smutny. [...]

Serce się we mnie trzepoce: moc mnie opuściła,

zawodzi nawet światło moich oczu.

Przyjaciele moi i sąsiedzi stronią od mojej choroby

I moi bliscy stoją z daleka ${ }^{19}$.

(Ps 38, 7. 11-12)

${ }_{16}$ M. Skwarnicki, Droga Krzyżowa z Janem Pawtem II. Wielki Piatek 1989 r., Koloseum, [w:] tenże, L. A. Moczulski, Przyciskam krzyż do serca. Drogi krzyżowe i medytacje pasyjne, Kraków 2006, s. 9.

${ }^{17}$ J. Kristeva, Martwy Chrystus Holbeina, [w:] Wymiary śmierci, wyb. S. Rosiek, przekł. R. Lis, Gdańsk 2002, s. 289.

${ }^{18}$ Tekst drogi krzyżowej został przygotowany i wydany z inicjatywy Centrum Dialogu i Modlitwy w Oświęcimiu. Działa ono na rzecz pojednania polsko-niemieckiego. Zajmuje się również edukacją dotyczącą problematyki zagłady.

${ }_{19}$ „Boże mój, Boże mój, czemuś mnie opuścit?” Droga krzyżowa w Auschwitz-Birkenau, oprac. M. Deselaers, Kraków-Oświęcim 2012, s. 12. Cytat z psalmu za niniejszym opracowaniem. 
Inność staje się znakiem choroby, która nie pozwala pozostałym spokojnie spoglądać na zainfekowanego człowieka, jego twarz i jego smutek przypominają bowiem o fakcie, iż śmiertelność to cecha naturalna każdego bytu. Chorobę, której dotyczą żale psalmisty, w kontekście obozowych realiów postrzegać można również jako wyznacznik tożsamości. Można rozumieć ją jako żydowskość, polskość, romskość, a także jako historyczność, w którą człowiek się wikła zupełnie nieświadomie, przychodząc na świat. Wkracza w czas określonych definicji, czyniących z jednej tożsamości właściwą $\mathrm{z}$ innej chora, skazaną na zagładę.

Męka Chrystusa, ukazująca jak łatwo jest unicestwić człowieka, przywołuje przed oczy człowieka kolejne skojarzenie, obraz śmierci zadanej. Także w rozważaniach oświęcimskiej drogi krzyżowej czytamy w ramach interpretacji drugiego upadku Jezusa (stacja VII): „Również w komorze gazowej przy krematorium III można było zabić cyklonem B nawet dwa tysiące ludzi naraz. Dentyści otwierali usta zwłokom i wyrywali obcęgami złote korony" ${ }^{20}$.To fakt, którego przywołanie niejako zaprzecza nadziei, jaka następuje w momencie, gdy upadły Jezus powstaje i rusza w dalszą drogę. Zamordowani, których liczbę podano w oparciu o dane statystyczne, w tym momencie kończą swoją drogę krzyżową. Przywołana w ramach rozważań wizja ludobójstwa wpisuje się ponadto w refleksję nad związkiem śmierci z władzą. Louis-Vincent Thomas w szkicu Tworzenie tanatologii powołał się na stwierdzenie Michaela Foucaulta, parafrazując jego myśl:

Już podporządkowanie się władzy jest śmiercią albo umieraniem, natomiast korzystanie z niej daje (niebezpieczne) złudzenie nieśmiertelności. Szantażowanie śmiercią przez władzę — która pozbawia nas i śmierci, i życia — jest takim samym podstępem, jak szantażowanie życiem [... $]^{21}$.

Przemijanie, jak już zostało powiedziane, wymyka się normom estetyki, co prowadzi do rozdźwięku między duchem (także myśla) — pretendującym do wieczności — a ciałem, ulegającym obumieraniu. Droga krzyżowa hiperbolizuje aspekt agonalny, ukazując momentalność i drastyczność śmierci. Ks. Szymon Mucha ${ }^{22}$, rozpoczynając rozważanie stacji VIII, spotkanie Jezusa z niewiastami jerozolimskimi, napisał: „Gdy kobiety zobaczyły zmasakrowaną postać Jezusa, wybuchły płaczem"23. Zwraca zatem uwagę na czysto ludzką, emocjonalną reakcję wywołującą litość i zapewne również strach. Te emocje przeplatają się, gdy spotykamy się z osobami niedołężnymi lub konającymi. Strach podzielenia czyjegoś losu potrafi odebrać chęć do życia, a przez to i pragnienie

${ }^{20}$ Tamże, s. 22.

${ }^{21}$ L.-V/ Thomas, Tworzenie tanatologii, przekł. M. L. Kalinowski, [w:] Wymiary śmierci, s. 13.

${ }^{22}$ Ks. Szymon Mucha podjął się organizowania w miejscowości Lipsko wielkopiątkowej drogi krzyżowej prowadzonej ulicami miasta. Tak powstała tradycja pasyjnej procesji, dokonującej się poza murami świątyni, a przy tym angażującej miejscową ludność, która reprezentuje różne grupy społeczne i zawodowe. Tym samym poszczególne stacje stają się zdarzeniem związanym z realnym miejscem i konkretnym człowiekiem oraz jego problemami. Ks. Mucha jest również autorem rozważań, które odczytywano podczas nabożeństwa. Zob. E. Frączyk, Przedmowa, [w:] Sz. Mucha, Droga krzyżowa ulicami miasta, Warszawa 2011, s. 5-7.

${ }^{23}$ Sz. Mucha, dz. cyt., s. 168. 
kształtowania go. Doświadczenie cudzej śmierci zatrzymuje nas na teraźniejszości, tymczasem procesualność, jaka towarzyszy poszukiwaniu sensu własnej egzystencji i pytaniu o charakter jej nieśmiertelności, nakazuje żyć przyszłością, zamierzeniem.

Wybieganie w przyszłość, intuicyjne lub uargumentowane wiarą w spełnienie, zostaje odzwierciedlone również w strukturze drogi krzyżowej, która często zostaje otwarta na XV stację, wspominającą zmartwychwstanie. Scena ta pochodzi z nabożeństwa drogi światła, w całości poświęconej obecności Chrystusa na ziemi po zmartwychwstaniu. XV stacja staje się wyrazem buntu przeciwko dysharmonii, która steruje współczesnym człowiekiem, stawiając go nieustannie w obliczu bezsensu za życia i pustki po śmierci. Siostra Imelda Kosmala, przywołując dzień powstania z grobu w swoim rozważaniu, niejako usprawiedliwia się zwracając do Chrystusa: „o Twoim zmartwychwstaniu / pamiętali przezorni wrogowie ${ }^{24}$. O Ow gest wybiegania w przyszłość można również skomentować słowami Jägera:

Po czasach kryzysu Boga (Johann Baptist Metz) i czasach ciemności Boga (Martin Buber) nastały teraz czasy głodu Boga. Ten głód jest egzystencjalny, wyrasta z głębi naszego ludzkiego jestestwa. Szukamy interpretacji naszego życia ${ }^{25}$.

Jäger posiłkował się medytacją, szukając w myśli Wschodu rozwiązań dla zinstytucjonalizowanego chrześcijaństwa, które, jego zdaniem, zbyt rozmiłowało się w śmierci. Otwarcie na zmartwychwstanie, symboliczne, poprzez ujmowanie sceny triumfu Chrystusa w ramach drogi krzyżowej, staje się, według niego, przejawem poszukiwania duchowej harmonii przez ludzi wierzących. Mistyka Jägera pretenduje do bycia mistyką odnowy współczesnego społeczeństwa, współczesnego człowieka. Traktuje ona o jedności z Absolutem (nie tyle zaś z Bogiem konkretnego wyznania), wyzbywając się symboliki języka religijnego. Staje się tym samym, w swym założeniu, nowoczesnym i praktycznym rozwiązaniem, kształtującym własny dyskurs „duchowy” daleki od skończonych form i zamkniętych definicji.

\section{DośWIADCZENIE ŻAŁOBY JAKO ELEMENT PASJI}

W strukturę drogi krzyżowej zostały wplecione również zachowania żałobne. Stacja VIII, gdy Chrystus spotyka płaczące niewiasty, stanowi obraz, który można odczytywać nie tylko jako przejaw litości, lecz również jako przepracowywanie straty. Strata ta dopiero nastąpi, według chronologii zdarzeń, lecz antyczna tradycja płaczek uczestniczących w pochodach żałobnych pozwala tej stacji zyskiwać wieloznaczność. To już nie tylko obraz profetyczny, lecz również aktorski lament i rzeczywiste opłakiwanie tego, który odchodzi.

„Jezus spotyka płaczące niewiasty”, Joanna Pociask-Karteczka ${ }^{26}$ zapisała zaś pod tym sformułowaniem następującą historię:

\footnotetext{
${ }^{24}$ M. I. Kosmala, dz. cyt. s. 82.

${ }^{25}$ W. Jäger, $d z$. cyt., s. 21.

${ }^{26}$ Joanna Pociask-Karteczka jest przyrodnikiem, pracownikiem naukowym Uniwersytetu Jagiellońskiego. Jej droga krzyżowa przyjmuje formę prywatnej, jeśli nawet nie intymnej refleksji.
} 
miał dopiero 24 lata i podobno muchy nie pozwolił skrzywdzić

był studentem matematyki

planował stypendium zagraniczne

zdążył całą Europę przemierzyć na rowerze

który zawiózł go pewnej nocy do Pana Boga

ale wcześniej spotkał dwóch nieletnich łotrów

bez wina i octu

zamiast włóczni mieli kije baseballowe

zatłukli go na śmierć

Michał Łysek 22 marca 1997 roku

miał dopiero 24 lata $^{27}$.

Autorka rozważań przedstawiła historię śmierci młodego człowieka, którego życie trwało zaskakująco krótko. Jednak nie tragiczny moment opuszczenia świata jest w tej relacji istotny, lecz miejsce, w jakim odnajdujemy je podczas drogi krzyżowej. To moment, gdy ten, który odchodzi, spotyka tych, którzy zostają. Spotkanie przyjmuje formę ostatecznego pożegnania, ponieważ sama chwila przejścia w wieczny sen jest chwilą największej samotności człowieka. Żałoba rozpoczyna się zatem już przed śmiercią. Jej pierwszym etapem jest skonfrontowanie się ze stratą — dla autorki rozważań stratą jest obiecujące życie młodego człowieka, studenta matematyki. Postanawia więc upamiętnić jego los, wpisując właśnie w tym granicznym i wieloznacznym momencie pasji Chrystusa postać $\mathrm{z}$ własnego świata. Nie poddaje się przy tym jeszcze lamentacji. Przedstawia fakt, ubierając go, co prawda, w język przynależny opowieści Jezusowej — pojawia się łotr, ocet, wino - Michał Łysek jednak w rzeczywistości ginie z rąk przypadkowych sprawców. Płacz, który ostatecznie rozlega się w dalszej części rozważań stacji VIII tejże autorki, nie jest płaczem nad grzeszną duszą doprowadzającą Chrystusa do śmierci — jest przejawem bezsilności wobec wątłości ludzkiego istnienia.

Kolejne etapy żałoby odnajdujemy w scenie nazywanej pietą oraz w scenie złożenia Chrystusa do grobu. Stacja XIII ukazuje moment, gdy ciało Chrystusa zostało zdjęte z krzyża i oddane Matce. Ks. Popiełuszko pisał o tej scenie:

„Maryja trzyma martwego Syna”

$\mathrm{Na}$ to, że teraz trzyma martwego Syna w swoich ramionach, zgodziła się już kiedyś, gdy powiedziała słowa: „Oto ja służebnica”. Wybrała los matki najnieszczęśliwszej i zarazem najszczęśliwszej².

Maryja została przedstawiona w tej refleksji jako osoba świadoma sytuacji i swojego w niej miejsca. Jej rola nie ograniczyła się zatem jedynie do bycia matką, która wydała na świat niezwykłe dziecko i straciła je w sposób nienaturalny, przedwcześnie. Obraz matki, który eksponują również słowa rozważań Jana Pawła II: „A Jezus znowu jest w Jej ramionach jak był w stajence betlejemskiej”29, stał się powszechną interpretacją piety. Został on jednak uzupełniony przez ks. Popiełuszkę o wizerunek Maryi podobny do tego, który wykreował komentator obrazu Pietera Breugela:

\footnotetext{
${ }^{27}$ J. Pociask-Karteczka, Droga krzyżowa, Kraków 2012, s. 13.

${ }^{28}$ J. Popiełuszko, dz. cyt., s. 29.

${ }^{29}$ Droga krzyżowa. Rozmyślania Jana Pawła II, Nowy Jork 1986, Stacja XIII.
} 
Przyszłość będzie się rozwijać później jako nowa siła dzięki tej kobiecej świadomości, uosabianej przez Maryję. Tymczasem jednak widzimy ją złamaną przez Prawo i Los, w ich ostatniej chwili triumfu ${ }^{30}$.

Stacja XIII to zatem moment, gdy opłakiwany jest Syn przez swoją Matkę, ale opłakiwany również jest stary porządek, który odchodzi wraz ze śmiercią Jezusa. Maryja płacze więc także nad sobą, jej ból zdaje się bowiem silniejszy od pewności własnych wyborów i powołania. To kolejny moment ukazujący dualizmy rządzące drogą krzyżową. Cierpienie i radość łączą się w niej tak jak i zwątpienie z nadzieją. Podobnie rzecz przedstawia się w ludzkim życiu i na ten aspekt odczytania postaci Matki i Syna zwrócił również uwagę Adam Rybicki:

W procesie humanizacji Jezusa i Maryi szczególne znaczenie miały dwie tajemnice ich życia: narodzenie Jezusa i Jego męka. W tych wydarzeniach zarówno Chrystus, jak i Maryja okazali się szczególnie ludzcy i bliscy każdemu człowiekowi ${ }^{31}$.

Złożenie do grobu, stacja wieńcząca drogę krzyżową, to równocześnie ostatni moment fizycznej obecności opłakiwanego. Z chwilą pogrzebania ciała pozostaje po człowieku jedynie ulotne wspomnienie. Dla uczestniczących w obrzędzie pochówku jest to zarówno moment ostatecznego rozstania. Czas ten zostaje objęty konwencją, nadając ramy cierpieniu i poniekąd wyznaczając jego oficjalny kres. Rytuał pogrzebowy, który przenika do tradycji pasyjnej poprzez procesję złożenia Chrystusa do grobu, mająca stałe miejsce w liturgii wielkopiątkowej, w mniej lub bardziej rozbudowanej formie kształtuje charakter przeżywania ostatniej stacji nabożeństwa drogi krzyżowej. Pieśni towarzyszące tym procesjom mają ludowy charakter. Śpiewnik Mioduszewskiego podaje utwór Dobranoc Głowo Święta ${ }^{32}$, w którym można dopatrzeć się cech kołysanki. Stylizacja ta świadczy o humanizacji treści sakralnej wyrażanej w formie ekspresji zaczerpniętej z codziennych praktyk człowieka. Ludowość można również zaobserwować w scenie wieńczącej rozważania Pociask-Karteczki. Opowieść o Józefie z Arymatei udającym się po ciało Chrystusa przeplata ona swoistym refrenem:

szabas z ostrym zapachem czosnku

szabas dla Boga wyuczonego na pamięć

szabas z sercem zamkniętym zardzewiałą kłódką

szabas szabas hoj la la la

szabas szabas hoj la la la ${ }^{33}$.

Tekst powtarzany kilkukrotnie wydaje się wyciszać sytuację, przywracać dawny porządek zmącony przez moment śmierci. Gest żałobników ma w tym przypadku

${ }^{30}$ M. F. Gibson, Mbyn i krzyż. „Droga krzyżowa” Pietera Breugela, przekł. A. Topornicka, [w:] M. F. Gibson, L. Majewski, Bruegel: Mtyn i krzyż, Olszanica 2010, s. 97.

${ }^{31}$ A. Rybicki, Compassio Mariae w chrześcijańskim życiu duchowym: studium na przykładzie polskiej średniowiecznej literatury i sztuki religijnej, Lublin 2009, s. 134-135.

${ }^{32}$ Śpiewnik kościelny czyli pieśni nabożne z melodyjami w kościele katolickim używane a dla wygody kościotów parafialnych przez X. M. M. Mioduszewskiego zebrane, Kraków 1838, s. 100-101.

${ }^{33}$ J. Pociask-Karteczka, dz. cyt., s. 23. 
charakter regresywny. Wpędza dodatkowo w stan otępienia, pewnej bezmyślności. Przyśpiewka ta nasuwa skojarzenie z tańcem. Staje się on chwilą zatracenia i jednocześnie oczyszczenia. Taniec jednoczy poprzez harmonię i wyzwala na skutek rytmu, przekształca statyczne w dynamiczne. Jest on jednak również formą krążenia. Można zatem postrzegać ten specyficzny rodzaj ruchu jako sposobność powrotu do stanu uprzedniego.

Scena tańca wieńczy także Młyn i krzyż, film w reżyserii Lecha Majewskiego (2011 rok), będący próbą ożywienia wspomnianego już obrazu Breughla Droga krzyżowa. Opowieść o Jezusie z Nazaretu, którego ukrzyżowanie przyciągnęło tłumy, kończy się powrotem do spokoju dnia powszedniego. Józef z Arymatei także mimowolnie poddał się porządkowi umiłowania harmonii. Pociask-Karteczka skomentowała jego poczynania w ten sposób: „szedł szybko by zabrać ciało / nie zważał że depcze Jego czerwone ślady" ${ }^{34}$. Strach przed śmiercią został zatem ostatecznie odrzucony a człowiek-żałobnik uratowany poprzez prawo, konwencję oraz umiejętność przywracania obalonego porządku.

Teksty dróg krzyżowych podejmują problematykę przemijania zarówno na poziomie narracji prymarnej, jak i w warstwie rozważań. Tradycyjny obraz pasji, który przywołują tematy kolejnych stacji, wskazują na lęk człowieka przed cierpieniem, słabość jego ciała, szybkość z jaką traci ono witalność, przywołują wreszcie wizję agonii i śmierci. Rozważania rozwijają te kwestie. Autorzy refleksji proponują nam zapis zindywidualizowanego doświadczenia pasyjnego. Przywołane przykłady rozważań potwierdzają tezę, iż myśl o przemijaniu jako zbliżaniu się do kresu życia, a także kwestia samej śmierci i żałoby po stracie bliskich osób, jest obecna we współczesnych tekstach dróg krzyżowych. Tym samym rozwinięty zostaje ludzki aspekt procesji na Golgotę. Cierpienia doczesne okazują się jej powtórzeniem.

Teksty dróg krzyżowych, jako realizacje ukształtowanej formy pasyjnej, stwarzają zatem możliwość zaistnienia w swej przestrzeni refleksji poświęconej ludzkiemu życiu jako całości - od młodości po starość. Śmierć oraz pogrzeb wieńczą tę opowieść, której narratorem jest człowiek. Mówi on o sobie samym, pozostając w lustrzanej relacji z Chrystusem. Na tej podstawie opiera się też podobieństwo kształtujące metaforyczne odczytywanie drogi krzyżowej. Człowiek stawia sobie Chrystusa za wzór do naśladowania. Jego mękę odczytuje więc jako skondensowany obraz ludzkiej egzystencji. Pretekstem do podjęcia problematyki młodości okazują się sceny, w których uczestniczą kobiety - przede wszystkim zaś postać Matki Chrystusa. Jej otwarte ramiona symbolizują początek ludzkiego życia. Natomiast scenę płaczu kobiet jerozolimskich wykorzystano do ukazania perspektyw młodego człowieka, jego nadziei i potencjału. Tym obrazom przeciwstawione zostaje wyobrażenie starości, przedstawionej przez

${ }^{34}$ Tamże, s. 23. 
pryzmat choroby, odrzucenia i agonii. Refleksja nad przemijaniem we współczesnych tekstach dróg krzyżowych przejawia się zatem poprzez konfrontację tego co witalne i dopiero zainicjowane (więc młode) z tym, co nieestetyczne i trudne do akceptacji (więc stare, skazane na śmierć).

Monika Bednarczyk

\section{Way of the Cross as the Metaphor of Evanescence}

Summary

Way of the Cross contains the last moments of Jesus's life. It begins with the judgment and ends when the body is entombed.

This story of Jesus's death can also be seen like a picture that shows human's life. Existential problems are written in Way of the Cross next to religious because of particular God's presence in human being. The evanescence is one of those issues, which are analysed by the authors of reflections fulfilling structure of 14 episodes that create Jesus way to Calvary.

The idea of this article is to show and analyse the examples of consideration the death and mourning taken from contemporary Way of the Cross texts. The analysis of them leads to conclusion that human looks for a confrontation with the picture of evanescence. This experience helps people to understand their nature which nowadays is displaced by society.

Słowa klucze: pasja, przemijanie, podobieństwo, Bóg, człowiek

Keywords: Passion, evanescence, similarity, God, human 